\title{
Factors affecting and shaping the General Managers' work in small and medium-sized luxury hotels: the case of Greece
}

\begin{abstract}
The work of General Managers (GMs) in hotels has been the focus of several empirical studies since the early 1980s. The majority of these studies were conducted in corporate or multinational (MNC) hotel chains' environment and often neglected the smaller independent operators and family businesses. This study explores the mediating factors that affect the GMs' work in small and medium luxury hotels (SMLHs); the context of this study is Greece, a popular tourist destination dominated by SMLHs. Based on a qualitative research approach, 16 in-depth interviews with GMs were conducted in four popular tourist destinations. Five key factors in relation to the GMs' work were found to be important: career development and mobility; contact intensity; owner-GM relations; dealing with corruption; and networking and reputation. The findings suggest a number of theoretical and managerial implications related to managerial work in SMLHs.
\end{abstract}

Key Words: Managerial work; Work context; General Managers; Hospitality; Small and Medium Luxury Hotels; Greece

\section{INTRODUCTION}

Despite the key role that hotel general managers (GMs) play in small and medium-sized business, research has focused on managers in national or international hotel chains where a high level of standardisation is expected, in terms of performance and managerial work patterns (Gannon et al. 2015; Nickson 1998). Our knowledge of managerial work in the small and medium-sized establishment context that represents the majority of hotels globally is limited to a number of empirical studies that either suffer from a small sample or poor design (Giousmpasoglou 2012). This study explores the factors affecting and shaping the GM's work in small and medium-sized luxury hotels (SMLHs) in Greece, a mature tourist destination dominated by small and medium-sized businesses. More specifically the GM's roles and relationships with key stakeholders such as hotel owners, staff and customers are 
investigated in the local (Greek) context. For the purpose of this study, the factors affecting and shaping GM's work roles in SMLHs are defined as the internal and/or external environment conditions at the local/regional, national and international level. A literature review on the SMLHs in the hospitality context as well as managerial work in hotels is provided in the following section. The research methodology and design are also discussed. Then, the following section presents and discusses the findings of this study. The final part discusses the conclusions and implications at both a practical and theoretical level.

\section{LITERATURE REVIEW}

\section{MANAGERIAL WORK ROLES}

Among the hundreds of distinct organisational work roles, few have received as much scholarly attention as that of the managerial role (Dierdorff et al. 2009). For a long time, writing about management focused on what, as an overall activity, it would achieve. Thus, prominent writers of the early 20th century like Max Weber, Herni Fayol and Frederic Taylor saw managerial work as rational, subject to planning and governed by the principles of time and motion to achieve efficiency with employees (Kakabadse et al. 2004). The 'classical' school was distilled in the work of Fayol (1949) who categorised managerial activities into a few basic tasks and procedures which applied to all administrative positions in hierarchical structures. Fayol's POC model (command, co-ordinate, control, forecast and plan, and organise) was the cornerstone of managerial work for the first half of the 20th century. While Fayol is clearly regarded as one of the founders of management thinking, his account of the functions of management tells us little about management and managerial work roles (Collins 2000).

During the 1950s and 1960s, scholars argued that the conceptual understanding of management was detached from actual managerial practice (Carlson 1951; Mintzberg 1973). As a reaction to that critique, a series of mostly descriptive studies were conducted during those decades (i.e. Martin 1956; Burns 1957; Sayles 1964; Stewart 1967), all contributing to the basic understanding of the characteristics and qualities of managerial work. This body of research has sought to delineate what managers do and how they can influence organisational functioning (Campbell et al. 1970; Shetty 1982). These early studies were, furthermore, criticised for recording 'behaviour', 'activities', 'tasks', and 'functions' without 
making any clear distinction between them (Hales 1986). They were also criticised for not connecting their findings to other studies of managers' jobs (Fondas and Stewart 1994) or to the stream of study focusing on the management process as a whole (Hales 1999). It was also argued that the coding approaches in earlier research appeared to be 'somewhat haphazard and arbitrary' (Martinko and Gardner 1985, p.688), and that these studies, having been done without any consistent categories or models, are difficult to compare (Hales 1986; Martinko and Gardner 1985).

Mintzberg's (1973) work appears as one of the most influential (Kakabadse et al. 2004) and at the same time controversial (Fondas and Steward 1994) on the study of managerial roles. On the basis of his research, Mintzberg formulated ten management roles and made thirteen propositions about the characteristics of managerial work (Mintzberg 1973, pp.5153). Based on his observations, Mintzberg contends that all managerial jobs are essentially alike in pace, variety, brevity and fragmentation. Thus, for Mintzberg the ten Interpersonal, informational and decisional roles (figurehead, leader, liaison, monitor, disseminator, spokesman, entrepreneur, disturbance handler, resource allocator, negotiator) are applicable to all levels of management. He also argues that differences in managers' jobs are with respect to the relative importance of roles according to the functional areas and levels in the hierarchies. These propositions describe managerial work in a rather precise and well-defined manner (reactive and fragmented behaviour, conducted at a relentless pace, preferably through verbal interactions). The propositions were based on the theoretical assumption that structural conditions determine managerial behaviour to a large extent.

Mintzberg's Role Model has been criticised by different scholars on different grounds (Snyder and Gleeck 1980; Steward 1982; Martinko and Gardner 1985). Mount and Bartlett (1999) summarise these critiques as follows: first, his sample is extremely small (five CEOs); second, he assumes CEOs represent typical managers; third, his sample does not allow testing of his assertions about function and level, and fourth, because simply describing 'what managers do' is not necessarily linked or related to effectiveness. Despite these criticisms, Mintzberg's ideas have been part of the management lexicon and are widely taught in business and hotel schools (Mount and Bartlett 1999).

About twenty years after his seminal study on the nature of managerial work, Mintzberg (1994) has made an attempt to create a conceptual framework that aimed to capture the whole of managers' work roles. According to Mintzberg, individuals come into managerial 
jobs with personal histories. They have values like honesty, integrity or morality. They also bring a body of experience, which expresses itself in terms of a set of skills or competencies and knowledge. An individual's knowledge may be used directly or indirectly to help interpret the various work situations encountered, for example, when an employee's absence from work becomes a pattern requiring attention. Mintzberg asserts that each individual has a set of mental models to interpret the world. All of these individual characteristics come together to influence how the manager approaches his or her job. This is referred to as the manager's style of managing. The manager is located within the frame for the job. The frame consists of three specific components. First is purpose, which is what the manager is seeking to do with the unit he or she is supposed to manage. The second component is perspective, which is the overall approach to the management of the unit; and the third is positions, which is about the specific strategies for how the job is done. The implication of this model was that, regardless of the managerial style adopted, a manager's work had to be 'well rounded', meaning that it should incorporate successfully all these primary and secondary roles in one unified activity: managing.

Mintzberg's model of managing is visually attractive and seems 'sound' (Kakabadse et al., 2004). Despite its soundness though, a major drawback with the model is that it fails to take into account the socio-cultural context in which the manager operates. As noted by Hales (1999), the model with the individual in the centre - both visually and analytically - suggests that the manager is an autonomous, proactive agent, able to choose and control his/her work pattern. This unbound-agent approach has been criticised for being too uncritical about the dualism between 'action' and 'system' (Willmott, 1987). According to Willmott (1987), the institutional conditioning and consequences of managerial work are either bracketed, taken for granted, or treated as an independent variable in most studies of managers' jobs. Drawing on this general critique, it could be argued that Mintzberg (1994) underestimates institutional constraints on managers' behaviour.

Despite the wealth of research on managerial work roles discussed above, literature indicates that a clear and coherent framework has not yet been established. The reason behind that according to Cortada $(2009$, p.15) is that management as science is still immature and needs to incorporate 'whole bodies of information' from other disciplines such as psychology and economics. It is argued that since the late 1990s, research on managerial work roles was diluted to the different areas of management studies i.e. operations management, 
marketing, human resource management, accounting and finance. Moreover, managerial work role studies focused on different sectors and sub sectors, i.e. differentiating managerial behaviour from services and manufacturing. The current study focuses on the nature of managerial work roles within the hospitality industry context. The following section discusses the existing studies regarding hospitality managers' roles.

\section{MANAGERIAL WORK IN THE HOSPITALITY INDUSTRY}

The existing literature on managerial work in hotels is limited to research conducted mainly in the 1980s and 1990s. Several empirical studies (e.g. Guerrier and Deery, 1998; Hales and Tamangani 1996; Nebel et al. 1995) suggest that hotel managers experience serious challenges, especially in luxury establishments where targets of service quality, customer satisfaction, effective people management and outstanding (financial) performance must be achieved for a highly personalised and perishable product (Bowie et al. 2016). It is also argued that hotel GMs need constantly to predict and deal with changes in the outside environment, which impact upon their sensitive product (Bharwani and Talib 2017).

The work of GMs in hotels is linked to the performance and overall success or failure of the business (Aissa and Goaied 2016; Hodari and Sturman 2014). The hotel GMs' roles and the context of effectiveness and performance were the focus of a considerable number of studies for more than two decades. Several researchers have replicated or tested Mintzberg's (1973) early work in the hospitality sector (i.e. Arnaldo, 1981; Ferguson and Berger, 1984; Kim, 1994; Ley, 1980; McCall and Segrist, 1980; Mount and Bartlett, 1999; Shortt, 1989). During the 1990s, there have been further studies of managerial work in the hospitality industry, notably by Nebel (Nebel and Ghei, 1993; Nebel et al., 1995) and Hales and Tamangani (1996). Two interrelated themes recur through this work, as well as in the earlier studies (Guerrier and Deery, 1998). The first theme explores the interaction between managerial work in hotels and the industry context. The second theme investigates the hotel managers' engagement to reaction or reflection. In this context the question of operational versus strategic roles makes an appearance for first time in hospitality literature: do hotel managers respond to immediate operational issues, or they do actually act as strategic resources of the organisation? In a notable effort to respond on the above questions, Nebel and Ghei (1993) developed a conceptual framework of the hotel GM's work roles (Table 1). 


\begin{tabular}{|c|c|c|c|}
\hline Time Frame & GM Job Function \& Roles & Key Job Demands & Key Relationship Issues \\
\hline 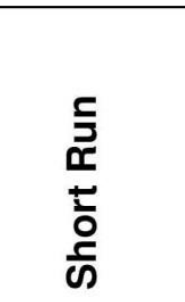 & $\begin{array}{l}\text { Operational Controller: } \\
\text { - Monitor and Disseminator } \\
\text { (of internal information) } \\
\text { - Disturbance Handler } \\
\text { - Resource Allocator } \\
\text { (of own time) } \\
\text { - Leader }\end{array}$ & $\begin{array}{l}\text { Day-to-day operational } \\
\text { control of service, costs, } \\
\text { and revenues. Intense } \\
\text { pressure to earn profits } \\
\text { and render high-quality } \\
\text { service. }\end{array}$ & $\begin{array}{l}\text { Intense and frequent } \\
\text { downward, internal verbal } \\
\text { communication and } \\
\text { interaction with hotel } \\
\text { subordinates. }\end{array}$ \\
\hline 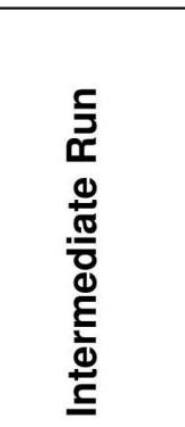 & $\begin{array}{l}\text { Organisational Developer: } \\
\text { - Liaison } \\
\text { - Monitor and Disseminator } \\
\text { (of both external \& } \\
\text { internal information) } \\
\text { - Entrepreneur } \\
\text { - Resource Allocator } \\
\text { (of own time, programs, } \\
\text { and funds) } \\
\text { - Leader }\end{array}$ & $\begin{array}{l}\text { Train and develop } \\
\text { subordinates. Fine-tune } \\
\text { hotel's service strategy to } \\
\text { changing external } \\
\text { environment. Develop and } \\
\text { refine the organisation } \\
\text { structure. }\end{array}$ & $\begin{array}{l}\text { Downward internal } \\
\text { communication. Lateral } \\
\text { communication with the } \\
\text { external environment. } \\
\text { Upward communication } \\
\text { with corporate superiors } \\
\text { and staff specialists or } \\
\text { owners. }\end{array}$ \\
\hline 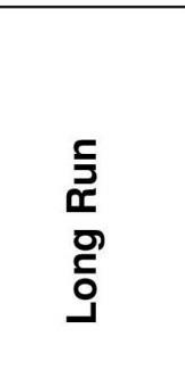 & $\begin{array}{l}\text { Business Maintainer: } \\
\text { - Liaison } \\
\text { - Monitor and Disseminator } \\
\text { (of external and internal } \\
\text { information) } \\
\text { - Resource Allocator } \\
\text { (of programs and funds) } \\
\text { - Entrepreneur } \\
\text { - Leader }\end{array}$ & $\begin{array}{l}\text { Capital expenditure } \\
\text { decisions in line with } \\
\text { hotel's strategic service } \\
\text { vision. Develop and } \\
\text { sustain organisational } \\
\text { stability and vitality. }\end{array}$ & $\begin{array}{l}\text { Downward internal } \\
\text { communication to further } \\
\text { stability and vitality. } \\
\text { Lateral communication } \\
\text { with the external } \\
\text { environment. Intense } \\
\text { upward communication } \\
\text { with corporate office or } \\
\text { owners. }\end{array}$ \\
\hline
\end{tabular}

Source: adapted from Nebel and Ghei (1993) cited in Rutherford and O'Fallon (2007), pp.94-97

Table 1: An integrated framework for the GMs' work roles, demands and relationships in hotels

Nebel and Ghei (1993) suggested that a hotel GM's job can be better understood by examining the contextual variables that influence and shape it. In addition they argued that the work context in hotels poses a series of job demands and relationship issues with which they must deal effectively in order to perform successfully. They also found that the time frame under consideration (short term, intermediate term, long term) affects these contextual elements (relationship issues and job demands). These considerations give rise to specific job functions that GMs perform through a variety of work roles. These job functions require GMs to be leaders, a work role they play through every contact with subordinates. 
Finally, Nebel and Ghei (1993) argue that these job functions need not be and often are not performed independently of each other.

In another study focused on hotel unit GMs work, Hales and Tamangani (1996) arrived at similar conclusions. They found that most of the day-to-day operational problems are service centred and therefore a key role of any hotel manager must focus on service quality management. They used as an example the emphasis retail unit managers place on reactive customer administration, and they argued that hotel managers should proactively concentrate on service quality management. They also suggested that most of the day-to-day work and customer related problems in hotels have short leadtimes. Whilst managers should also concern themselves with the medium and long term needs (with emphasis on staff development) 'the pressing needs of the immediate and recurrent often drive out longerterm considerations' (Hales and Tamangani, 1996, p.748).

During the early 2000s the changing balance of the importance of acquiring management skills versus operational skills was contested by US scholars (e.g. Chung - Herrera et al. 2003; Kay and Russette 2000; Perdue et al. 2000). These studies argue that hospitality managers have much in common with managers from other sectors especially those with higher hierarchical levels; it is also argued that there is still support for operational skills training, but hotel managers acknowledge the growing importance of managerial and leadership skills in enhancing the performance of the hotel. Kay and Moncarz (2004) suggest that besides human skills, ability in information technology, financial management and marketing are also important for a hospitality manager's success. In the current decade (2010s), research identifies five broad areas in relation to GMs' responsibilities: strategy, operations, marketing, human resources, and finance (Hodari and Sturman 2014). The emergence of these five areas indicates that the work of hotel GMs has evolved from operational to strategic level at least in corporate and multinational hotel chains (Bharwani and Talib 2017; Gannon et al. 2015).

A few studies (e.g. Hodari et al. 2017; Hodari and Sturman 2014; Turner and Guilding 2013) also investigate the relationship between owners and GMs and the level of GMs' autonomy based on the hotel's size and governance structures (independent, franchised, and managed). The findings suggest that independent hotel GMs operate in a greater level of autonomy provided by the hotel owners, especially when the GMs are experienced (Hodari and Sturman 2014). A number of benefits that arise from high autonomy levels include: increased motivation and job satisfaction (Salazar et al. 2006); burnout and turnover 
minimisation (Kim et al. 2007); improved decision making (Takeuchi et al. 2008); and better performance (Morgeson and Humphrey 2008). The key argument against GM autonomy is a potential loss of control over the property. As a result GMs in hotel chains have greater authority in human resources, marketing, and strategy but limited autonomy concerning finance and operations (Gannon et al. 2015; Hodari et al. 2017).

\section{MANAGERIAL WORK IN SMLHs}

Small and medium-sized enterprises (SMEs), which make up $81 \%$ of all businesses within the European Union (European Commission no date) are defined as employing up to 250 people. The existing literature on small and medium luxury hotels ( $\mathrm{SMLH}$ 's) is limited to a few empirical studies spread in different cultural, country and industry contexts (Dale and Robinson 2007); it is argued that the lack of homogeneity and the great diversity in terms of work patterns and company profile, renders the study of small businesses challenging (Morrison 1996). Research on SMLHs identifies a number of managerial challenges. Kearney et al. (2014) identifies a number of key managerial challenges in small Irish hotels namely: owner/manager dominance; lifestyle motivation; market proximity; human resource management; embeddedness; simple structure; informal communication; decision making based on heuristics/intuition. The owner-manager appears as a central figure and a critical factor for the survival of the business.

Furthermore, it is argued that the relationship between the owner and the general manager (GM) is a pivotal yet unexplored area in SMLHs; the only account in this area comes from Turkey, where Birdir (2002) suggests that conflict between hotel GMs and owners very often results to high turnover of GMs. Both the informal nature of communication (Wagner et al. 2003) and Human Resources Management (HRM) practices (Hoque and Bacon 2006) appear as key challenges in the SMLH literature. Conversely, Kearney et al. (2014) propose that the owner-manager has also close relationships with the local community (provides jobs, participates in local community events, act as an ambassador) and an extensive network of other stakeholders such as suppliers, local authorities and business partners. 


\section{METHODOLOGY}

The aim of this study is to explore the factors that affect and shape the GMs' work roles in SMLHs. This study draws on rich data to situate 'localised' experiences from the social actors themselves (Burrell and Morgan 1979), the hotel GMs. The present research used an interpretive paradigm to examine the interaction of managerial work with context (Dierdorff et al. 2009; Korica et al. 2017; Johns 2006). Thus the research approach took an interpretive perspective that was committed to a social constructivist philosophy (Burrell and Morgan 1979).

\section{RESEARCH DESIGN}

The tools employed for this qualitative research were in-depth semi-structured interviews supported by field observations. A 14-question interview guide was employed, the questions emerging from the reviewed literature and the research objectives. The interview questions probed SMLH GM's work in the following areas: recruitment and selection; training and development; GM's roles; performance appraisal; relations with stakeholders (i.e., hotel owners, customers, employees, suppliers); networking; hotel ownership status; and cultural/contextual influences.

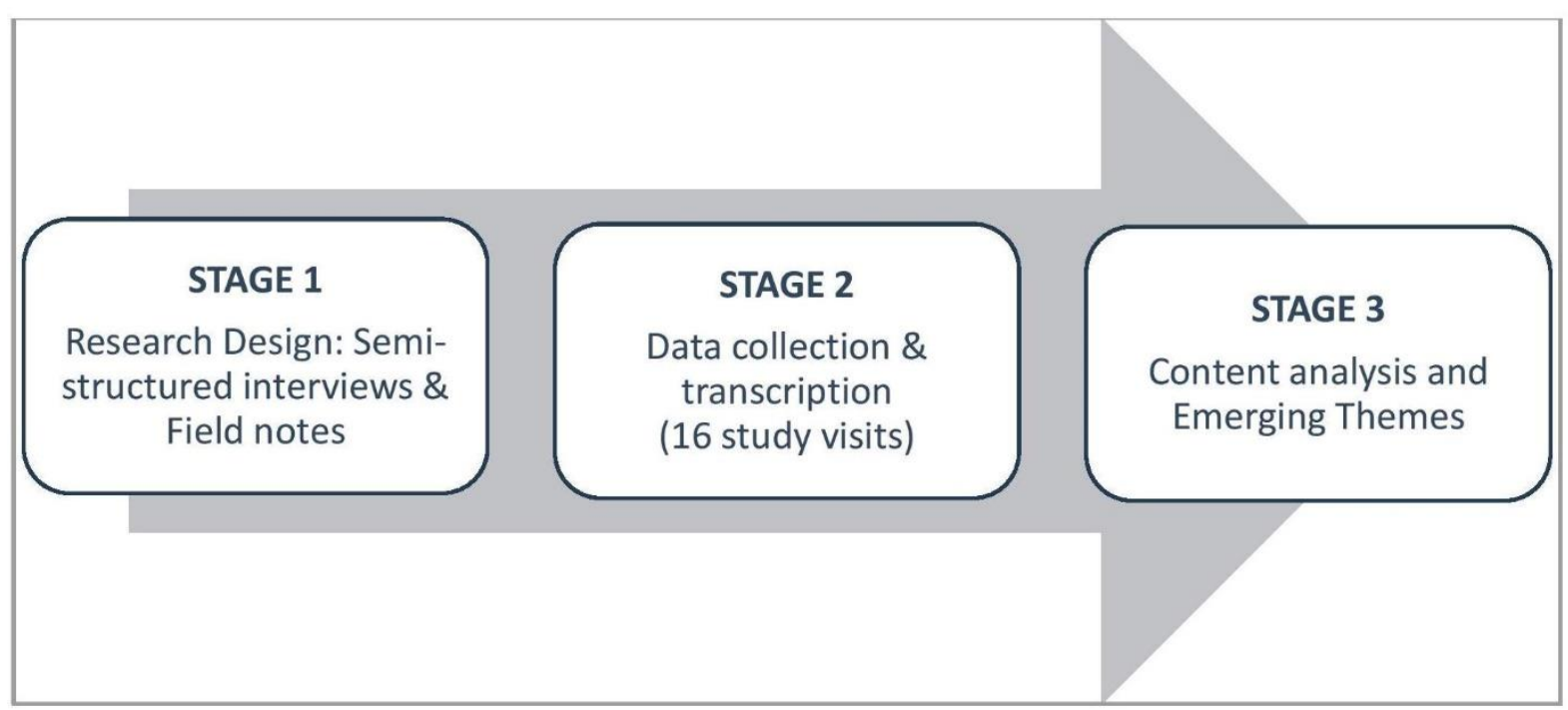

Figure 1: Research design

A three-stage approach was followed in the planning and delivery of the field work. An analysis of the Greek luxury ( $4^{*}$ and $5^{*}$ ) hotel sector was conducted in order to decide on the potential participant GMs and ways to secure access. Given the number and geographical 
spread of the luxury hotels in Greece (Table 2), a purposive sample with 16 hotel units was employed in this research (Bryman 2015); all hotels in the sample had the same star rating $\left(4^{*}\right.$ and $\left.5^{*}\right)$, were the same type (city or resort), and the same size ( $<250$ employees). They were also all either family-owned (single independent hotels and local chains) or hotel units of a national Greek chain. Multinational chains were excluded. Field work took place at the most representative and popular destinations for city and resort hotels respectively (Table 3). This was achieved by comparing quantitative data retrieved from the databases of the National Statistics Agency (www.statistics.gr), the Greek National Tourism Organisation (www.gnto.gr) and the Hellenic Chamber of Hotels (www.grhotels.gr).

\begin{tabular}{|c|c|c|c|c|c|c|}
\hline \multicolumn{7}{|c|}{ Number of Hotels / Rooms / Beds / Employees by star ratting } \\
\hline & 5* & $4^{*}$ & 3* & 2* & 1* & Total \\
\hline Hotels & 444 & 1.412 & 2.472 & 3.990 & 1.412 & 9,730 \\
\hline Rooms & 67,407 & 104,562 & 96,033 & 111,842 & 27,302 & 407,146 \\
\hline Beds & 137,210 & 203,203 & 185,560 & 210,365 & 52,215 & 788,553 \\
\hline Employees & 125.7 & 37.9 & 13.6 & 5.7 & 3.5 & \\
\hline \multicolumn{7}{|c|}{ Employment in Hotels } \\
\hline $\begin{array}{l}\text { No. of } \\
\text { Employees }\end{array}$ & $1-5$ & $6-10$ & $11-25$ & $26-50$ & $51-100$ & Over 100 \\
\hline Percentage & $56.10 \%$ & $17.50 \%$ & $14.50 \%$ & $5.60 \%$ & $3.80 \%$ & $2.4 \%$ \\
\hline
\end{tabular}

Table 2: Hotels in Greece

All potential participants were contacted through e-mail and telephone within a period of three months. Data collection required visits to four popular tourist/visitor destinations, namely Athens, Thessaloniki, Crete and Rhodes. Four hotels were selected in each destination; each hotel visit incorporated data collection through the employment of interviews and field observations. Field notes (Emerson et al. 2011) were recorded during and after each visit; the notes contained information from informal conversations with members of staff and hotel guests. The content of these conversations was related to the hotel GMs' interaction with the guest and staff and how these groups perceived the GMs' work. 


\begin{tabular}{|c|c|c|c|c|c|c|c|c|}
\hline $\begin{array}{l}\text { Hotel } \\
\text { Coding }\end{array}$ & $\begin{array}{l}\text { Ownership } \\
\text { Status }\end{array}$ & $\begin{array}{l}\text { Hotel } \\
\text { Type }\end{array}$ & $\begin{array}{c}\text { Hotel } \\
\text { Star } \\
\text { Rating }\end{array}$ & $\begin{array}{c}\text { No. of } \\
\text { staff }\end{array}$ & $\begin{array}{l}\text { GM's } \\
\text { Gender }\end{array}$ & $\begin{array}{l}\text { GM's } \\
\text { Age }\end{array}$ & $\begin{array}{c}\text { GM's } \\
\text { Marital } \\
\text { Status }\end{array}$ & $\begin{array}{c}\text { GM's } \\
\text { Education } \\
\text { Level }\end{array}$ \\
\hline H1 - Ath & GR/L/Ch & City & $5 *$ & 160 & Male & over 50 & Married & $\mathrm{BSc} / \mathrm{Pgd}$ \\
\hline $\mathrm{H} 2$ & $\mathrm{GR} / \mathrm{N} / \mathrm{Ch}$ & City & $5 *$ & 110 & Male & $40-50$ & Married & ASTER/BSC \\
\hline H3 & $\mathrm{GR} / \mathrm{N} / \mathrm{Ch}$ & City & 5* & 90 & Male & $40-50$ & Married & ASTER/BSC \\
\hline $\mathrm{H} 4$ & FAMILY & City & $4 *$ & 93 & Male & over 50 & Married & ASTER/PgD \\
\hline H5 - Thes & $\mathrm{GR} / \mathrm{N} / \mathrm{Ch}$ & City & 5* & 110 & Male & $40-50$ & Married & ASTER/BSC \\
\hline H6 & $\mathrm{GR} / \mathrm{N} / \mathrm{Ch}$ & City & 5* & 80 & Male & over 50 & Married & ASTER/PgD \\
\hline $\mathrm{H7}$ & $\mathrm{GR} / \mathrm{N} / \mathrm{Ch}$ & City & $4 *$ & 102 & Male & $40-50$ & Married & ASTER \\
\hline $\mathrm{H8}$ & FAMILY & City & 5* & 100 & Male & over 50 & Married & ASTER \\
\hline H9 - Crete & FAMILY & Resort & $5^{*}$ & 149 & Female & $30-40$ & Married & ASTER \\
\hline H10 & $\mathrm{GR} / \mathrm{N} / \mathrm{Ch}$ & Resort & $4^{*}$ & 235 & Male & $40-50$ & Single & $\mathrm{BSc} / \mathrm{MSc}$ \\
\hline H11 & GR/L/Ch & Resort & 4* & 65 & Male & $30-40$ & Married & TEI \\
\hline H12 & GR/L/Ch & Resort & $4^{*}$ & 84 & Male & $40-50$ & Married & BSC \\
\hline H13 - Rho & $\mathrm{GR} / \mathrm{N} / \mathrm{Ch}$ & Resort & $5 *$ & 240 & Male & $40-50$ & Married & $\mathrm{BSc} / \mathrm{MSc}$ \\
\hline H14 & GR/L/Ch & Resort & $5 *$ & 215 & Male & $40-50$ & Married & ASTER/TEI \\
\hline H15 & FAMILY & Resort & 4* & 64 & Female & $40-50$ & Married & ASTER/PgD \\
\hline H16 & $\mathrm{GR} / \mathrm{N} / \mathrm{Ch}$ & Resort & $5 *$ & 194 & Male & $30-40$ & Married & $\mathrm{BSc} / \mathrm{MSc}$ \\
\hline \multicolumn{9}{|c|}{$\begin{array}{l}\text { Staffing levels: the figures provided refer to hotels operating in maximum occupancy during the high season. } \\
\text { The staffing levels can drop to }-40 \% \text { to }-50 \% \text { during the low season. }\end{array}$} \\
\hline \multicolumn{3}{|c|}{$\begin{array}{l}\text { Ownership status } \\
\text { Family: Greek family owned hotel; } \\
\text { GR/L/Ch: Greek local chain hotel; } \\
\text { GR/N/Ch: Greek national chain hotel }\end{array}$} & \multicolumn{3}{|c|}{$\begin{array}{l}\text { Locations } \\
\text { Ath: Athens; } \\
\text { Thes: Thessaloniki; } \\
\text { Rho: Rhodes; } \\
\text { Crete: Chania area }\end{array}$} & \multicolumn{3}{|c|}{$\begin{array}{l}\text { Education } \\
\text { ASTER: Hotel School } \\
\text { TEl: Polytechnic } \\
\text { BSc: Bachelor of Science } \\
\text { MSc/MA/PgD: Postgraduate } \\
\text { Studies }\end{array}$} \\
\hline
\end{tabular}

Table 3: Participant hotels' and GM's background combined information

The interviews varied in length from 45 to 60 minutes. A confidentiality agreement was signed by both parties prior to the interview in order to comply with this study's ethical standards. The content of this document covered areas such as participant consent, deception avoidance, withdrawal terms, confidentiality and participant protection (Neuman and Robson 2014). The hotel visits lasted from 5 to 10 hours and included a hotel inspection (visit the hotel's departments and key operations areas with a senior manager) and informal 
conversations with members of staff recommended by the GM. A research protocol was followed in order to eliminate potential bias and ensure through standardisation, valid and reliable data (Yin 2015). All interviews were conducted in English and voice recorded by the author.

Shortly after each visit, interview transcriptions were prepared by the author and the data collected were organised and stored for future processing. The completion of the data collection was followed by the data analysis, the final stage of this research. A serious consideration at this stage was to decide upon the approach to be used on data analysis. The qualitative nature of this research required the production of a rich set of data (Bryman 2015), which viewed the topic under study from different angles. Thus, qualitative content analysis (Eriksson and Kovalainen 2015) was selected as the most suitable method in order to identify the factors affecting and shaping SMHL GMs' work. Alongside the interview transcriptions and field notes, company documents (e.g. job descriptions, company standards) and electronic media (e.g. websites, brochures) were also used. The final phase of this stage was the triangulation of data (Decrop 1999), meaning the combination of data from these diverse sources (interviews, observation logs and miscellaneous documents) in order to identify commonalities and differences among the participating hotel GMs. The presentation and discussion of these results will be the focus of the following section.

\section{FINDINGS AND DISCUSSION}

Based on the content analysis of the data collected in this study, five emerging themes identified as factors affecting and shaping the GMs' work in Greek SMLHs, namely: career development and mobility; contact intensity; owner-GM relations; dealing with corruption; and networking and reputation. The discussion of these themes as well as the conditions under which they are formed, follows below.

\section{FACTOR 1: CAREER DEVELOPMENT AND MOBILITY}

Geographical mobility and mobility between companies (Ladkin, 2002) emerged as an integral part of the SMLH GMs' progression and career development. Throughout their careers, luxury hotels' GMs were expected to relocate or move to another company; the frequency of these 
changes depended on the manager's career choices. During the interviews, managers reported that it was very common to see GMs from family hotels moving to local chain hotels and vice-versa. Based on the findings it can be argued that, regardless of the potential organisational and cultural compatibility, the GMs adapted to certain roles required in the new working environment. In a similar manner, management mobility was observed in hotel chains, where the majority of the managers who worked in Greek national hotel chains have already been employed in multinational chains. More rarely, a family or local hotel chain GM could move to a national hotel chain, especially when the latter was faced with scarcity of suitable candidates:

Back in the early 2000s, just before the 2004 Olympics the company made a very big expansion... 24 hotel openings within a year... at that time we had to lower our standards and recruit GMs with relatively poor background (meaning in family hotels)... our priority was to open these hotels (emphasis). (GM-H2)

The level of mobility and cross national / international experience of GMs was viewed as a very difficult aspect to manage within the national hotel chains. In particular, aspiring GMs were expected to be mobile and to facilitate their own mobility through their language proficiency, eagerness to work and live with other cultures, and their lack of domestic ties. Based on the above finding, it is argued that national chains attract a certain type of hotelunit GM: "We avoid recruiting "old school" hotel managers (over 50) ... we prefer to develop younger talented managers with knowledge, ambition and enthusiasm for work' (GM-H5). This fact was also supported by the participant GM's profile in this research; the average age for hotel chain GMs was between 40 and 50 , whereas family hotel GMs were past their 50 s, in near retirement age. Management mobility was clearly affected by the manager's age and family status in this study. Hotel chains emphasised on the GM's professional and academic qualifications and its potential for development, while family hotels appreciated experience and seniority.

Moreover, the 'work-life' balance for hotel managers posed one of the greatest challenges for managerial career choices in this sector (Deery and Jago 2015). All participants identified the importance of mobility and age, either in terms of the rise in dual career couples, concern over children's education or hopes of 'settling down'. A female GM in Crete argued that 'if I had to decide which profession to do for the rest of my working life I would do this again...but I wouldn't recommend it to my children'(GM-H9). Despite the fact that 
managers were overall satisfied with their jobs and optimistic about spending the rest of their working lives in Greek SMLH, they could not suggest the same for the new 'breed' of managers - those who had graduated since the mid-1990s up to today. A near retirement hotel GM from an Athenian local chain argued that:

...the young generation is extremely unlucky... they are talented, well-educated but unfortunately they have extremely limited options for career development in this country especially after the 2008 economic crisis... I would recommend all young graduates to try their luck abroad in multinational companies where they can boost their potential. (GM-H1)

Another factor that affected the managers' career choices and mobility was compensation (Maroudas et al. 2008). In an informal chat with a GM during the study visit to an Athenian national hotel chain, it was admitted that 'there are many managers who decide to leave the company and work even in family hotels if the money is good (emphasis)' (GMH2). Family and local chain hotels were willing to pay above the average market rate in order to attract senior managers for chains, especially in remote destinations throughout Greece. On the other hand national chains and multinationals offered the promise of career development, moderate salaries and frequent relocations, at least for senior managers.

Management mobility was also influenced by the available options in career paths (Ladkin 2002). During the interviews, GMs argued that there were limited career path options in order to become a GM in Greek luxury hotels: either by starting a career in the Food and Beverage (F\&B) department, and/or less frequent in the Rooms Division or Front Office (F/O) department. The Food and Beverage department as a significant stepping-stone to the GMs' career was also reported in literature (e.g. Giousmpasoglou 2012; Ladkin 1999; Nebel et al. 1995). On the other hand the majority of participants acknowledged that, alongside the recognition that wider business skills are important for GMs, most of the revenue created by hotels originated from the rooms side rather than the provision of food and beverage. More experienced GMs worked in both departments in order to acquire a holistic hotel operations' view. While this career path (from the Food and Beverage department) was very common in family hotels and local and national hotel chains, it was not followed in big Greek national chains. Those chains emphasised functions such as Sales, Marketing and Finance background for appointing senior management positions. The development of the required GMs' skills was achieved through the employment of mentoring, training and/or management 
development programmes. In addition, among the participant managers there was a belief that the advent of hospitality degree programmes led to more managers attaining such qualifications before embarking on a career as hotel manager. Nonetheless while educational provision influenced the quality of GMs there was still a wide diversity of qualifications and abilities across cohorts of GMs.

Finally, the creation of strong internal labour markets in national hotel chains was the main driver for internal management mobility (Jago and Deery 2004). The reasons for the extensive use of internal labour markets were based on supply side arguments and on advantages accruing inside each company. These included opportunities to perpetuate corporate culture, adverse prior experiences of external recruitment and problems in adjustment and effective hotel management by external candidates.

\section{FACTOR 2: CONTACT INTENSITY}

Contact intensity with hierarchical superiors, subordinates, staff, suppliers and customers emerged as another key factor affecting managerial work in SMLH. The findings suggest that the contact intensity with the owners and/or their representatives escalates from very high in family owned hotels to very low in national chains. GMs employed in all types of Greek hotels (family, local and national chains) reported close co-operation with the owners; the required competencies here were good listening skills, honesty, patience, sincerity, trust, and diplomacy. An experienced, near-retirement GM at an Athenian family-owned hotel (GM-H4) provided a graphic view of the ownership representatives by saying that 'it really depends on the person...most of the [family] hotel owners in Greece are not educated or they are just incompetent to run their business properly'. A Cretan local chain GM argued that:

...you shouldn't panic when the owner expresses his wills and wants... in addition, you should not demonstrate subordination... what you need to do is to show that you have the knowledge, the know-how to achieve the desired results... patience is a virtue when you deal with hotel owners in Greece. (GM-H12)

On the other hand, more formalised relationships were reported in national chains:

You need to have clear articulated proposals and be able to explain everything in detail...hotel owners are like any other businessmen they need a good rationale and justification before they give you any money to spend. (GM - H16) 
A national survey by the Tourism Research Institute (2009) concludes to similar findings regarding the relationship between the hotelier and GM in Greek hotels. Managers who worked in national chains did not report directly to the owner, but to senior corporate executives at regional or head office level. A GM in Rhodes said: 'a lot of diplomacy' is involved in this process...it is not enough to be good, you also need allies to support you in the head or regional office...unfortunately it is not easy to identify friends from foes...you have to be a strong character in order to survive this game' (GM-H13). Despite the clearly defined and communicated performance criteria for senior managers in national chains, a hidden agenda appeared to exist in the relationship between the hotel unit GMs and their superiors in the regional or the head office.

The following two types of people associated with the hotel GMs' work were their immediate subordinates (assistant GMs and department managers) and the staff. A great emphasis in teamwork was given in most of the responses referred to subordinate managers. A national chain GM in Thessaloniki described the managers' relationships in the following words:

Our management team works together as a family...we even go out together with our families and friends...despite our disagreements we manage to achieve what we want because of this special relationship...we all trust and support the current GM...he is like father to us. (GM-H7)

GMs were also required to encounter (to a certain degree) the hotel's suppliers; they can be divided into two broad categories: those supplying the hotel with goods like foods, beverages, sanitary materials, and equipment and those supplying the hotel with customers - in most of the cases travel agents and tour operators. Managers employed by Greek familyowned and local chain hotels followed a 'carrot and stick' approach by keeping safe distances from the suppliers. The reason for this approach was best described in the words of the local chain GM in Crete:

If you let them give you any kind of 'treats' then you are finished...you have to carefully select and closely monitor all your suppliers constantly...in the long term building relations of trust with your suppliers is very important if you want to have a peace of mind in this business... after all it's a win-win situation, or at least it should be. (GMH11)

An Athenian family-owned hotel GM highlighted the importance of the tour operator's reputation as a key selection criterion: '...from our own side it is very important to be able to 
keep your word - do not promise more than you can deliver, otherwise it is very easy to lose business' (GM-H4). The integrity and reputation problems did not reach most of the managers employed by national chains since goods, equipment and customer suppliers were largely pre-determined from the head or regional office. There was relatively little room for manoeuvre in this case and if one considered the internal audits and quality monitoring mechanisms, it was very hard for a GM to deviate, regardless his/her authority and power:

We exert tight price and quality controls in our food and beverage suppliers... there are very high and strict standards in their selection...we always bind them with contracts that do not leave any room for 'grey' areas. (GM-H10)

The last group related to the GMs' contact intensity was the hotels' customers. Managers were more talkative here, and provided a wealth of opinions, the bottom line of which was the same: 'the customer is the king'; 'the customer is our real employer'; 'customers are the A-Z of our work'. The participants emphasised 'soft' competencies like understanding, empathy, warmth, patience and personal contact. A Greek national chain GM in Rhodes noted:

We try to provide luxury services with a human approach; luxury cannot happen without the warm smile and kindness of our staff... we make considerable efforts to fulfil all of our customers' needs and wants without showing it. (GM-H16)

Another issue stressed by GMs concerned mostly family-owned and local chain hotels was the importance of repeat clientele ('repeaters'):

Almost forty percent of our clientele are repeaters, there are the hotel's best advertisement... what they get here is this family environment, something they cannot find in their countries... there is no room for customer complaints and misunderstandings... sometimes however they have unreasonable requests... when for instance we make major or smaller changes in the hotel's facilities they tell us how we should or shouldn't have done this... it is really difficult to explain them that this was done for their own sake. (GM - H9)

Indeed, observations during the hotel visits revealed that all managers in resort family and local chain hotels had regular contact with 'repeaters' throughout the day: a warm welcome during the arrival; a big smiley 'good morning' in breakfast; friendly advice on which place to visit. 'Repeaters' were treated as members of the extended hotel family. In return, those customers maintain contact with the GMs during the winter by e-mails, postcards, or even sent small gifts for the manager's family. While managers in family businesses and local 
chain hotels followed a warm and friendly approach in customer handling, their national chains counterparts adopted a more 'professional' behaviour:

We are trying to handle and resolve rapidly any customer complaint or problem... our staff is trained to do this in a uniform manner regardless department or rank... we make sure that our repeaters get always a little bit more of what they want...the secret of our success: excellent service quality customised to the customer's needs and standardised product... there is no room for unpleasant surprises when dealing with customers in luxury hotels. (GM-H3)

GMs were not involved in customer 'handling' unless the case was serious (e.g. theft, injury, etc.) or the guest was a VIP. Line managers were responsible for customer complaints; difficult cases followed the chain of command (line manager, department manager, assistant GM, GM). It should be noted however that during the study visits, national chain GMs were observed to spent some time 'around' the hotel talking to customers and staff. Although they receive information from their assistants, GMs wanted to have first-hand knowledge of the various issues that arose in the hotel throughout the day (and night).

\section{FACTOR 3: OWNER - GM RELATIONS AND LEVEL OF AUTONOMY}

The status of the GM position exerts power and creates demarcation lines, communicated in various ways, formally and informally within the hotel. The limits of the GM's authority (Hodari and Sturman 2014) and the visibility of those demarcation lines were found to be different in each hotel type. Thus, in family and local hotel chains, a rather confusing pattern appeared to exist regarding the GM's status and authority. Despite the superficial 'good rapport' with the owner and his/her family, GMs reported problems such as conflicting interests and fierce 'disagreements'. There were also cases where the managers were 'caught in the middle' of disagreements between family members and for instance the GM's authority to make decisions might undermined or removed by the owner or the owning family: '...they [the owner and his son] often disagree on the way they should run the hotel... in this case you just sit in the corner and listen (emphasis).' (GM-H4)

On the other hand the paternalistic management style blended with the 'family-like' atmosphere in family and local chain hotels created problems in people management which is characterised by high levels of informality (Giousmpasoglou 2014). Moreover, the recruitment of the GM's next of kin (relatives and friends) to various positions led to political behaviour and the creation of 'in-groups' and 'out-groups' among members of staff. Thus, the 
existence of 'clans' that supported or opposed the GM was not uncommon in the hotel units under study. Another problem that was raised by GMs was subordinates' reluctance to delegate. For example, middle and senior managers first consulted with their superior in order to take a decision, despite the fact that they can avoid this.

A different situation was reported in national hotel chains where the existence of clear hierarchical demarcation lines was communicated through the hotel unit's organisational chart. The status and authority of the GM could not be challenged and ownership interventions were rare. Relations with the immediate subordinates were loose, friendly, and team work was appreciated. Nevertheless, the GM had the final word and bore responsibility for all important decisions at hotel unit level. In addition, the GM acted as father figure and leader for managers and staff. Regarding the latter, all GMs employed in national chains mentioned that they sought good relations but at the same time maintained a hierarchy and a safe distance from staff:

I am trying not to chat in the hotel's corridors in order to avoid gossip, this is something that can ruin your career you know... nevertheless you have to respect your staff, be fair and honest, otherwise it is very easy to lose the game... just spend some time informally and listen to them, but for God's sake not in the corridors (laughs). (GM H16)

There was only one occasion where the owner played an active role at least at strategic level alongside the GM. In this case the researcher had to suspend an interview for 15 minutes due to a telephone 'brief of the day' conversation between the GM and the hotel owner. GMs reported that Greek national hotel chain owners trust their GMs in order to make important (strategic) decisions; on the other hand GMs were required to be able to provide clearly articulated and well documented proposals in order to be able to persuade their employers to invest money or resources.

\section{FACTOR 4: DEALING WITH CORRUPTION}

One of the greatest challenges reported for $\mathrm{GMs}^{\prime}$ work in SMLHs was the encounter with the wider Greek public sector. Greece's public sector suffers from widespread and high corruption levels that severely affects the business environment and market competitiveness (GAN Integrity, no date; The Economist 2014). In this study, a substantial number of public services, authorities and agencies were connected with the capacity of the hotel to operate legally and 
comply with the country's health and safety regulations. According to Transparency International (2017) most problems appear in businesses' transactions with the public sector, due to relatively high levels of corruption. Those who for some reason (preference, cost, contacts etc.) could not deal with [corrupt] central or local bureaucrats, tended to choose the grey side of the economy, making it complementary to a corrupt state (Bolton et al. 2018); GM-H15 argued that 'it doesn't matter if you obey the law... at the end of the day you'll have to bribe somebody to process your case!'

In addition, most of the interviewees responded that the manager's integrity against corruption was of paramount importance. The 'course of action' for managers against corruption escalated from a 'hands-on' approach in family-owned and local chains, to 'acknowledgement' and 'monitoring' in national chains. Social intimacy appeared as a key strategy for GMs in family and local chain hotels; they kept strong social or even family relations with 'key people' - not necessarily high ranked - in local authorities and public sector organisations:

There will be always a friend or relative to help you overcome bureaucracy in the public sector... this is quite helpful especially during 'visits' from the police, health and safety officers, etc... although we have nothing to be afraid of, we receive warning phone calls in order to avoid unpleasant surprises (emphasis). (GM-H12).

When this was not feasible, GMs used their networks and connections to approach those who would help the GM to achieve his/her objective. The situation was best described in the words of an experienced near-retirement manager:

I'm not proud to say but I had to bribe low or medium rank public servants a few years ago in order to get my job done... unfortunately this is how it works in this country... there were signs of improvement during the past ten years but we still have a long way to go if we want to consider ourselves Europeans. (GM-H4)

Greek national chain managers reported that they were aware of this situation but it did not affect their job since most transactions with the public sector were contracted by others (e.g. the hotel's accountants and legal advisors or even directly by the head office). There were however references that GMs in national chains make sure that they know or at least have access to the 'right' people in local communities, 'just in case of a potential difficult, hard to resolve situation' (GM-H2). 
Corruption existed and persisted in many shapes and forms despite the existence of corporate Codes of Conduct and the adoption of Corporate Social Responsibility (CSR) programmes (Holcomb and Smith 2017) in hotels. Only a very small fraction of unlawful activities such as bribes and engagement with organised crime was reported. This does not necessarily mean that the participant hotel GMs were corrupted. Local intermediaries who were able to approach the 'right' people, conducted the 'transactions' (e.g. bribes) on behalf of the companies. Although the GMs had no involvement at all in these 'transactions', they were fully briefed by the company. It can be argued that the data collected from the hotel visits did not allow further reflection in this area, since all managers considered it as a 'sensitive issue' and felt uneasy when this issue was raised during the interviews. The available data however in conjunction with a wealth of Greek and international research evidence (e.g. Cuervo-Cazurra 2016; Zacharakis et al. 2017) indicated clearly that the encounter of hotel GMs with corruption influenced to a certain degree the manager's work.

\section{FACTOR 5: NETWORKING AND REPUTATION}

Networking and reputation (Mintzberg 1994) played an integral part in SMLHs managerial work (Bharwani and Talib 2017). Networking secured valuable information from the hotel's external environment while the manager's reputation worked as a stepping-stone in terms of career progression. According to the research findings, the $\mathrm{GM}^{\prime}$ 's views were grouped into two categories: those from family and local chains, and those from the national chains. In the first category networks and reputation were valued as highly important not only for the $\mathrm{GMs}^{\prime}$ work but for the hotel itself. Hotel GMs maintained an extensive range of contacts outside their workplace, in local, regional and national level. This network provided the GMs with any kind of information that would possibly help them assess situations and take decisions. These networks were closely related to the manager's reputation; GMs worked hard to be acknowledged as 'very good' or 'excellent' professionals by the local, regional or national market. An Athenian local chain GM argued that 'a GM's name (reputation) is very important... it creates prestige for the hotel...helps also the hotel's reputation and enhances the brand name especially in family business...makes it easier for the company to do business' $(\mathrm{GM}-\mathrm{H} 1)$. There were also voices that criticised this process:

...it is easier to create a good reputation in Greece because the criteria for being a good $\mathrm{GM}$ are not clear...abroad assessment is more strict...a good name might help you find 
staff, good prices, suppliers or even a new job...networking happens also abroad and also there GMs help each other, see for example the EHMA (European Hotel Managers Association). (GM-H4)

It was also found that the younger GMs' refusal to participate in the 'established' networks, led to social and professional exclusion from the local GMs' 'in-group'. An experienced Rhodian GM commended: '...this (networking) is necessary evil, you can't avoid it... you have to play with the older guys' rules, otherwise they will find ways not only to block but to destroy your career (emphasis).' (GM-H8)

While the managers' networks and reputation criteria were vague in family and local chain hotels, there was a more systematic and transparent approach in Greek national chains. The GMs in this category were encouraged by their companies to create 'corporate networks' in order to help each other; help also came from the head office and the senior executives who worked there. There were also other networks from previous jobs or from the GM's activity outside the hotel:

...it is very important to know people in and out the hotel...GMs networking in Greece expands throughout the country... especially for those who are members in [hotel GMs] Associations it is easier to build a very big network which covers not only GMs but suppliers, tour operators, local authorities, etc. (GM-H16)

Outside the company limits, GMs made certain that they knew all the important or key people in the local community and public services. A GM's reputation in this hotel type was created through hard work and the acceptance of his/her colleagues. The latter was equally crucial to the former and was rooted to the 'in-group-collectivism' phenomenon met in the Greek culture (Chhokar et al. 2013; Giousmpasoglou 2012).

Based on the above, it was found that managerial reputation and networking were highly valued and appreciated by all luxury hotel GMs in Greece. The social settings and the different approaches used by GMs, according to the ownership status of the hotel, appeared as critical factors for securing membership in professional networks and creating good reputation.

\section{CONCLUSIONS}


This study identified five contextual factors that affect (to a certain degree) the SMLH GMs work, namely: career development and mobility, contact intensity, owner-GM relationship and autonomy, dealing with corruption, and networking and reputation (Figure 2).

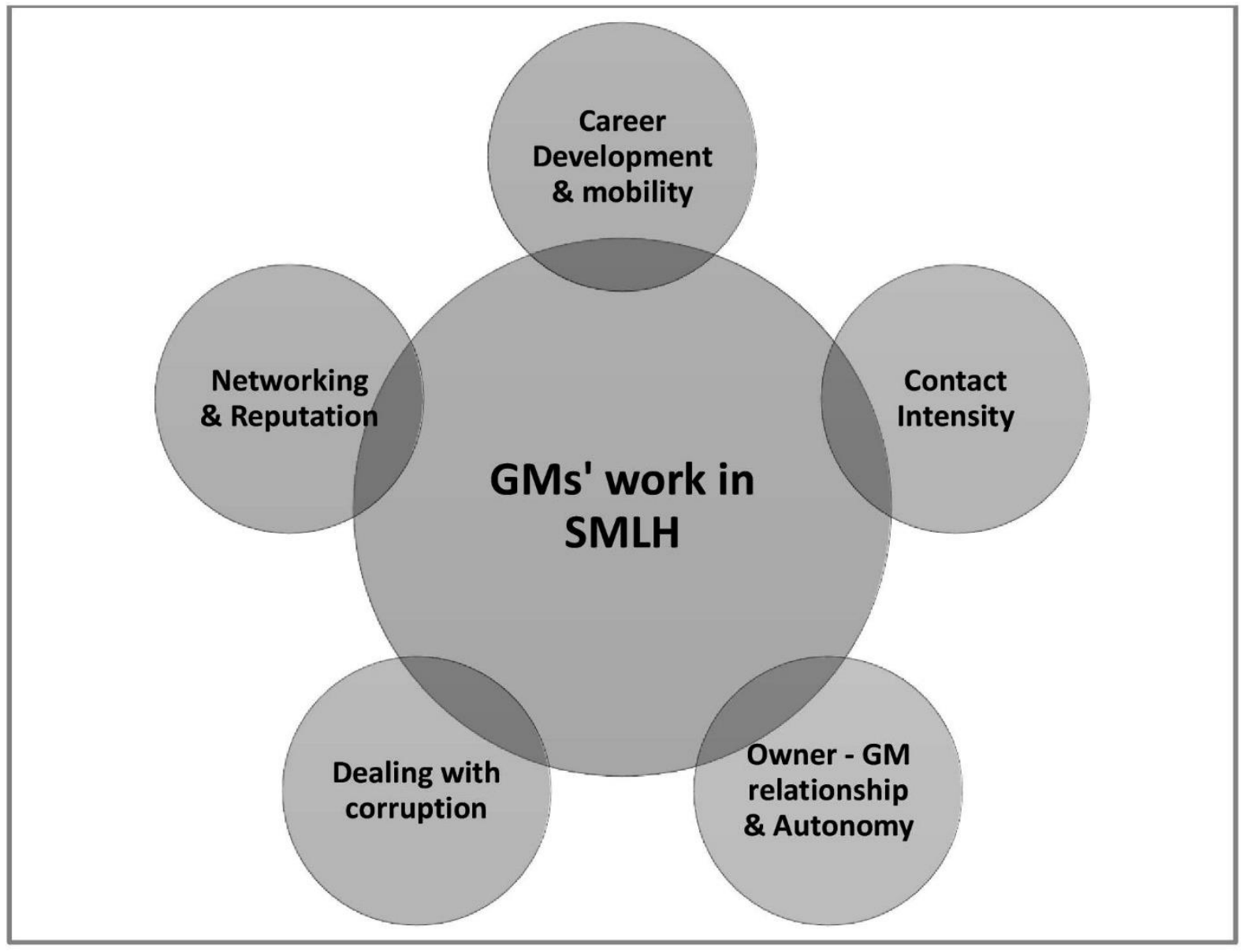

Figure 2: Factors affecting and shaping GMs' work in Greek SMLHs

Career development and management mobility emerged as the first contextual factor; the findings suggest that there were limited career path options in Greek SMLHs, where F\&B and Front Office appeared as the only departmental option for career progression (Giousmpasoglou 2012; Ladkin 1999). In national hotel chains the situation was different, because finance, sales and marketing offered additional career paths (Bharwani and Talib 2017).

Contact intensity appeared as the most important influence on SMLH GMs' work. GMs communicated daily with a broad spectrum of internal and external stakeholders, including owners, ownership representatives, subordinates, staff, customers, local authorities' officers/public servants. The contact intensity with each of these to a degree determined the 
managerial role (Mintzberg 1994). In Greek family hotels the effectiveness of a hotel manager was considered dependent on effective contact with the key stakeholders such as the owner, staff, customers, suppliers and the local authorities (Hodari and Sturman 2014), whereas this was not the case for national hotel chain GMs.

The relationship between the owner and the GM emerged as the following factor, probably because of its impact upon the GMs' autonomy, for two reasons. First, GMs of independent and local hotel chains appeared to have a difficulty delimiting their status and authority. The high levels of ambiguity and informality, the owner's involvement in day-today operations and interventions such as the appointment of family members and acquaintances as members of staff all confused the chain of command. In contrast the hierarchy Greek hotel chains was strictly formulated and communicated clearly throughout the organisation. The results appeared to some extent consistent with the few existing studies on GMs' autonomy (e.g. Hodari and Sturman 2014; Hodari et al. 2017; Turner and Guilding 2013).

GMs' integrity was another important mediating factor. Although the perceived high level of corruption in the Greek public sector was considered a sensitive issue, all GMs acknowledged the problem. The independent and local hotel chains GMs suggested that they dealt with the public sector and local authorities' corruption and bureaucracy, with little or no support from their company. In contrast, GMs from national hotel chains reported that they had no dealings personally with the public sector, but did have contacts to ask for help if needed. The impact of corruption and lack of transparency on managerial work in hotels is also reported in countries / regions such as Russia (D'Annunzio-Green 2002), the Caribbean (Jayawardena and Haywood 2003), Nigeria (Taiwo and Ward 2016), China (Ke et al. 2017) and Central America (Kubickova and Smith 2017).

Reputation and networking were considered as highly important by the majority of participant managers. However different individuals and groups of managers varied in the way they networked and sought to build their reputations. Managers in independent and local chain hotels had to work very hard to build a reputation, especially in the regional or national market, and the key to this was identifying the 'right' networks. National chains encouraged networking with other managers within the company, but these managers also maintained a lot of contacts outside the company. Reputation was not valued so highly within a hotel chain, where GMs were appointed for their performance and qualifications. 
The five contextual factors emerged from this research were responsible for the SMLH GMs' 'unique' individualised profile, since they shaped and affected each manager's development and exercise of individual work roles. The above findings are consistent with Mintzberg's role model $(1973,1994)$ and the hotel GMs' work roles identified by Nebel and Ghei (1993) discussed previously in the literature review.

\section{MANAGERIAL AND THEORETICAL IMPLICATIONS}

This study contributes to the current literature on GMs' work in a non-corporate environment, focused in small and medium-sized business context. More specifically, this study explores the influence of contextual factors such as mobility and networking in managerial work. The study provides a better understanding of managerial work outside the corporate and multinational hotel chain environment context. From a theoretical perspective, the management literature assumes that GMs in the hospitality, tourism and leisure sectors (e.g. hotel managers) are expected to behave and work in a standardised 'universal' manner (Gannon et al. 2015). This study suggests that even though managers may adopt similar practices, roles and competencies, they interpret and use them in a different 'individualised' manner as a response to the existing mediating factors. The role of the internal and external context here is crucial since it affects managerial work greatly. It is also argued that national culture may affect to a certain degree managerial behaviour in family businesses, whereas in large hotel chains the organisational culture remains largely unaffected. There are also 'inbetween' situations where a 'hybrid' model uses both national and corporate culture to better adapt on the local/national conditions. Therefore, this research contributes to the literature on managerial work by understanding how GMs adapt their work roles according to existing contextual conditions.

From a practical perspective, there are several human resource management implications closely related to the recruitment, development and retention approach used for GMs in small independent businesses. The experience, reputation and level of education are critical factors to consider when recruiting GMs for independent operators. The level of autonomy provided is linked to performance and the survival of the business. In addition, the nature of the relationship between the GM and the different stakeholders in smaller businesses makes it difficult to identify and recommend a set of 'successful' HR practices and 
strategies. It is therefore argued that each GM must be evaluated and treated initially during the selection process and later during the performance appraisals, based on the individual's qualifications in relation to the work context.

On the other hand, those aspiring to be luxury hotel GMs should be in position to identify the key challenges attached to this job. It is also argued that the demanding nature of the GMs' job requires talented and qualified individuals who understand the value of continuous personal and professional development, even in mature career stages. A key aspect of managerial work is understanding context. For example, frequent relocations require GMs to quickly develop contextual awareness so that they can adapt to new environments to function efficiently and productively. The current dynamic and volatile business environment requires hotel GMs to understand the norms and culture of their company, and adapt these to the local environment. A standardised approach in the way roles and competences are adopted is almost impossible to achieve, since each individual must decide what works best personally for them. Another key aspect of the GMs' work is the ability to work within 'professional' networks to keep abreast of what is happening at all levels of the market, including the job market. Hotel managers are expected to progress within the industry, but traditional career paths (through Food \& Beverage and Front Office departments) are not adequate for a new cohort of aspirant hotel GMs who must also acquire generic business skills.

As with any research this study's findings should be treated with caution. The purpose of this study was to identify the factors that affect and shape SMLH GMs' work; it was not clear if and how these factors interact and influence each other. Future research can explore the potential correlation and interaction of the five factors that emerged from this study. In addition, future research can also focus on the GMs' work context in other countries, where SMLHs have a considerable market share in the hospitality industry. As a concluding thought the findings of this study might contribute to the redesign of hospitality management curricula, enabling future managers to cope with a fast growing body of job-related requirements especially in non-corporate environments. 


\section{REFERENCES}

Aissa, S.B. and Goaied, M. (2016), 'Determinants of Tunisian hotel profitability: The role of managerial efficiency', Tourism Management, 52, pp.478-487.

Arnaldo, M.J. (1981), 'Hotel General Managers: a profile, Cornell Hotel and Restaurant Administration Quarterly', 22:3, pp.53-56.

Bharwani, S. and Talib, P. (2017), 'Competencies of hotel general managers: A conceptual framework', International Journal of Contemporary Hospitality Management, 29:1, pp.393-418.

Birdir, K. (2002), 'General Manager turnover and root causes', International Journal of Contemporary Hospitality Management, 14:1, pp.43-47.

Bolton, SC., Charalampopoulos, V. and Skountridaki, L. (2018), 'Selective consent and dissent: Professional response to reform in the post-crisis Greek NHS', Work, Employment and Society, p.0950017018774244.

Bowie, D., Buttle, F., Brookes, M. and Mariussen, A. (2016), Hospitality marketing, London: Taylor \& Francis.

Bryman, A. (2015), Social research methods, Oxford: Oxford university press.

Burns, T. (1957), 'Management in Action', Operational Research Quarterly, 8:2, pp.45-60.

Burrell, G. and Morgan, G. (1979), Sociological Paradigms and Organisational Analysis, Aldershot: Gower.

Campbell, J.P., Dunnette, M.D., Lawler, E. E., and Weick, K.E. (1970), Managerial behavior, performance, and effectiveness, New York: McGraw-Hill.

Carlson, S. (1951), Executive Behaviour, Stockholm: Strömbergs.

Chhokar, J.S., Brodbeck, F.C. and House, R.J. (eds)(2013), Culture and leadership across the world: The GLOBE book of in-depth studies of 25 societies, London: Routledge.

Chung-Herrera, B., Enz, C., and Lankau, M. (2003), 'Grooming Future Hospitality Leaders: A Competencies Model', The Cornell Hotel and Restaurant Administration Quarterly, 44:3, pp.17-25.

Collins, D. (2000), Management Fads and Buzzwords: Critical-Practical Perspectives, London: Routledge

Cortada, J. (2009), 'Power and use of context in business management', Journal of Knowledge Management, $13: 3$, pp.13-27

Cuervo-Cazurra, A. (2016), 'Corruption in international business', Journal of World Business, 51:1, pp.35-49.

D’Annunzio-Green, N. (2002.), 'An examination of the organizational and cross-cultural challenges facing international hotel managers in Russia', International Journal of Contemporary Hospitality Management, 14:6, pp.266-273.

Dale, C. and Robinson, N. (2007), Strategic imperatives for tourism SMEs in Europe. Tourism in the New Europe: Perspectives on SME Policies and Practices, Oxford: Elsevier.

Decrop, A., (1999), 'Triangulation in qualitative tourism research', Tourism management, 20:1, pp.157-161.

Deery, M. and Jago, L. (2015), 'Revisiting talent management, work-life balance and retention strategies', International Journal of Contemporary Hospitality Management, 27:3, pp.453-472.

Dierdorff, E., Rubin, R. and Morgeson, F. (2009), 'The Milieu of Managerial Work: An Integrative Framework Linking Work Context to Role Requirements', Journal of Applied Psychology, 94: 4, pp.972-988

Emerson, R.M., Fretz, R.I. and Shaw, L.L., (2011), Writing ethnographic field notes, Chicago: University of Chicago Press.

Eriksson, P. and Kovalainen, A. (2015), Qualitative methods in business research: A practical guide to social research, London: Sage.

European Commission (no date), Entrepreneurship and Small and medium-sized enterprises (SMEs), https://ec.europa.eu/growth/smes en. Accessed 27 February 2018.

Fayol, H. (1949), General and Industrial Management, London: Pitman 
Ferguson, D. H. and Berger, F. (1984), 'Restaurant Managers: what do they really do?' The Cornell Hotel and Restaurant Administration Quarterly, 25:1, pp.27-38.

Fondas, N., and Stewart, R. (1994), 'Enactment in managerial jobs: a role analysis', Journal of Management Studies, 31:1, pp.83-103.

GAN Integrity (no date) Greece corruption report, https://www.business-anti-corruption.com/countryprofiles/greece/. Accessed 29 October 2018.

Gannon, J.M., Roper, A. and Doherty, L. (2015), 'Strategic human resource management: Insights from the international hotel industry', International Journal of Hospitality Management, 47, pp.65-75.

Giousmpasoglou, C. (2012), 'A contextual approach to understanding managerial roles and competencies: the case of luxury hotels in Greece', Ph.D. thesis, Glasgow: University of Strathclyde.

Giousmpasoglou, C. (2014), 'Greek management and culture', European Journal of Cross-Cultural Competence and Management, 3:1, pp.51-67.

Guerrier, Y. and Deery, M. (1998), 'Research in hospitality human resource management and organizational behaviour', International Journal of Hospitality Management, 17, pp.145-160.

Hales, C. (1986), 'What Do Managers Do? A Critical Review of the Evidence', Journal of Management Studies, 23:1, pp.88-115.

Hales, C. (1999), 'Why do managers do what they do? Reconciling evidence and theory in accounts of managerial work', British Journal of Management, 10, pp.335-350.

Hales, C. and Tamangani, Z. (1996), 'An investigation of the relationship between organisational structure, managerial role expectations and managers' work activities', Journal of Management Studies, 33, pp.731-756.

Hodari, D. and Sturman, M.C. (2014), 'Who's in charge now? The decision autonomy of hotel general managers', Cornell Hospitality Quarterly, 55:4, pp.433-447.

Hodari, D., Turner, M.J. and Sturman, M.C. (2017), 'How hotel owner-operator goal congruence and GM autonomy influence hotel performance', International Journal of Hospitality Management, 61, pp.119-128.

Holcomb, J.L. and Smith, S., (2017), 'Hotel general managers' perceptions of CSR culture: A research note', Tourism and Hospitality Research, 17(4), pp.434-449.

Hoque, K. and Bacon, N. (2006), 'The antecedents of training activity in British small and medium-sized enterprises', Work, employment and society, 20(3), pp.531-552.

Jago, L. and Deery, M. (2004), 'An investigation of the impact of internal labour markets in the hotel industry', The service industries journal, 24:2, pp.118-129.

Jayawardena, C. and Haywood, K.M. (2003), 'International hotel managers and key Caribbean challenges', International Journal of Contemporary Hospitality Management, 15:3, pp.195-198.

Johns, G. (2006), 'The essential impact of context on organizational behavior', Academy of Management Review, 31:2, pp.386-408.

Kakabadse, A., Bank, J. and Vinnicombe, S. (2004), Working in organizations, 2nd Edition, Aldershot: Gower.

Kay, C. and Moncarz, E. (2004), 'Knowledge, Skills, and Abilities for Lodging Management Success', The Cornell Hotel and Restaurant Administration Quarterly, 45:3, pp.285-298.

Kay, C. and Russette, J. (2000), 'Hospitality Management Competencies', The Cornell Hotel and Restaurant Administration Quarterly, 41:4, pp.52-63.

Ke, B., Liu, N. and Tang, S. (2017), 'The effect of anti-corruption campaign on shareholder value in a weak institutional environment: Evidence from China', https://papers.ssrn.com/sol3/papers.cfm?abstract id= 2963478 Accessed 14 September 2018.

Kearney, A., Harrington, D., and Kelliher, F. (2014), 'Exploiting managerial capability for innovation in a microfirm context: New and emerging perspectives within the Irish hotel industry', European Journal of Training and Development, 38:1/2, pp.95-117. 
Kim, H.J., Shin, K.H. and Umbreit, W.T. (2007), 'Hotel job burnout: The role of personality characteristics', International Journal of Hospitality Management, 26:2, pp.421-434.

Kim, S.M. (1994), 'Tourist hotel general managers in Korea: a profile', International Journal of Hospitality Management, 13:1, pp.7-17.

Korica, M., Nicolini, D. and Johnson, B., (2017), 'In search of "managerial work": Past, present and future of an analytical category', International journal of management reviews, 19:2, pp.151-174.

Kubickova, M. and Smith, S.J. (2017), 'Role of destination competitiveness and national corruption in hotel performance: A study of developing economies of Central America', International Journal of Hospitality \& Tourism Administration, pp.1-24.

Ladkin, A. (1999), 'Hotel General Managers: A Review of Prominent Research Themes', International Journal of Tourism Research, 1:3, pp.167-193.

Ladkin, A. (2002), 'Career analysis: a case study of hotel general managers in Australia', Tourism Management, 23:4, pp.379-388.

Ley, D.A. (1980), 'The effective GM: leader or entrepreneur?' The Cornell Hotel and Restaurant Administration Quarterly, 21:3, pp.66-67.

Maroudas, L., Kyriakidou, O. and Vacharis, A. (2008), 'Employees' motivation in the luxury hotel industry: The perceived effectiveness of human-resource practices', Managing leisure, 13(3-4), pp.258-271.

Martin, N. (1956), 'Differential decisions in the management of industrial plant', Journal of Business, 29:4, pp.249-260.

Martinko, M., and Gardner, W. (1985), 'Beyond Structured Observation: Methodological Issues and New Directions', Academy of Management Review, 10:4, pp.676-695.

McCall, M.W. and Segrist, C.A. (1980), In pursuit of the manager's job: Building on Mintzberg, Greensboro: Center for Creative Leadership.

Mintzberg, H. (1973), The nature of Managerial Work, New York: Harper \& Row.

Mintzberg, H. (1994), 'Rounding out the Manager's Job', Sloan Management Review, Fall, pp.11-26.

Morgeson, F.P. and Humphrey, S.E. (2008), 'Job and team design: Toward a more integrative conceptualization of work design', in M.R., Buckley, J.R.B., Halbesleben and A.R. Wheeler (eds) Research in personnel and human resources management, Emerald Group Publishing Limited, pp. 39-91.

Morrison, A., (1996), 'Guest houses and small hotels', in P., Jones (ed.), Introduction to Hospitality Operations, London: Cassell, pp. 73-85.

Mount, D.J. and Bartlett, A.L. (1999), 'The managerial role assessment survey: Design and test of an instrument measuring Mintzberg's roles among hotel managers', Journal of Hospitality and Tourism Research, 23:2, pp.160175.

Nebel, E. C. and Ghei, A. (1993), 'A conceptual framework of the hotel general manager's job', Hospitality Research Journal, 16:3, pp.27-37.

Nebel, E.C., Lee, J. and Vidakovic, B. (1995) Hotel general manager career paths in the United States, International Journal of Hospitality Management, Vol.14, No.3/4, pp.245-260.

Neuman, W.L. and Robson, K. (2014), Basics of social research, Toronto: Pearson Canada.

Nickson, D. (1998), 'A Review of Hotel Internationalisation with a Particular Focus on the Key Role Played by American Organisations', Progress in Tourism and Hospitality Research, 4, pp.53-66.

Perdue, J., Ninemeier, J., Woods, R. (2000), 'Competencies required for club managers', Cornell Hotel \& Restaurant Administration Quarterly, 41:2, pp.79-85.

Rerres, K. (2012), Employment in the Tourism Sector. Athens: Research Institute for Tourism (in Greek), https://www.e-kyklades.gr/images/PAROUSIASIMELETIS F756.pdf. Accessed 11 February 2018.

Rutherford D. and O'Fallon, M. (Eds)(2007), Hotel Management and Operations, 4th Edition, New Jersey: John Wiley \& Sons Inc. 
Salazar, J., Pfaffenberg, C. and Salazar, L. (2006), 'Locus of control vs. employee empowerment and the relationship with hotel managers' job satisfaction', Journal of Human Resources in Hospitality \& Tourism, 5:1, pp.1-15.

Sayles, L. R. (1964), Managerial Behaviour, New York: McGraw-Hill.

Shetty, Y.K. (1982), 'Management's role in declining productivity', California Management Review, 25:1, pp.3347.

Shortt, G. (1989), 'Work activities of hotel managers in Northern Ireland: A Mintzbergian analysis', International Journal of Hospitality Management, 8:2, pp.121-130.

Snyder, N.H. and Glueck, W.F. (1980), 'How Managers Plan - the analysis of managers' activities', Long Range Planning, 13, pp.70-76.

Stewart, R. (1967), Managers and their jobs, London: McMillan.

Stewart, R. (1982), 'A model for understanding managerial jobs and behaviour', Academy of Management Review, 7:1, pp.7-13.

Tourism Research Institute (2009), The relationships between hotelier and GM, Athens: Tourism Research Institute (in Greek).

Taiwo, A. and Ward, T. (2016), 'Recruitment experiences in an international hotel chain in Nigeria', Worldwide Hospitality and Tourism Themes, 8:2, pp.211-215.

Takeuchi, R., Shay, J.P. and Jiatao, L. (2008), 'When does decision autonomy increase expatriate managers' adjustment? An empirical test', Academy of Management Journal, 51:1, pp.45-60.

The Economist (2014), 'Greece's shadow economy: The treasures of darkness'. https://www.economist.com/ finance-and-economics/2014/10/11/the-treasures-of-darkness Accessed 14 September 2018.

Thomas, D.C. (2008), Cross-Cultural Management: Essential Concepts, 2nd Edition, London: Sage.

Transparency International (2017). Country Profiles: Greece, https://www.transparency.org/country/GRC. Accessed 25 February 2018.

Turner, M.J. and Guilding, C. (2013), 'Capital budgeting implications arising from locus of hotel owner/operator power', International Journal of Hospitality Management, 35, pp.261-273.

Wagner, B.A., Fillis, I. and Johansson, U. (2003), 'E-business and e-supply strategy in small and medium sized businesses (SMEs)', Supply Chain Management: An International Journal, 8:4, pp.343-354.

Willmott, H. (1987), 'Studying Managerial Work: A Critique and a Proposal, Journal of Management Studies', 24:3, pp.249-270

Yin, R.K., (2015), Qualitative research from start to finish, $2^{\text {nd }}$ Edition, London: Guilford Publications.

Zacharakis, G.P., Antonopoulou, P.I., Travlos, A.K. and Kipreos, G.S. (2017), 'Corruption and Illegal Payments in Greece', Journal of Public Management Research, 3:1, pp.29-40. 